\title{
Taxonomic studies in Grevillea triternata and Grevillea ramosissima (Proteaceae: Grevilleoideae)
}

\author{
Peter M. Olde \& Neil R. Marriott
}

\begin{abstract}
Olde, Peter M. ${ }^{1}$ E Marriott Neil R. ${ }^{2}\left({ }^{1} 138\right.$ Fowler Rd., Illawong, NSW, Australia 2234; ${ }^{2}$ P.O. Box 107, Stawell, VIC, Australia, 3377). 1994. Grevillea triternata and Grevillea ramosissima (Proteaceae: Grevilleoideae). Telopea 5(4): 773-779 . Grevillea triternata R. Br. and G. ramosissima Meisn. are reviewed resulting in recognition of one new species, G. raybrownii P. Olde \& N. Marriott and of a subspecies, G. ramosissima subsp. hypargyrea (F. Muell.) P. Olde \& N. Marriott based on G. ramosissima var. hypargyrea $F$. Muell. for which a lectotype is designated. Notes on affinities and distribution are included as well as keys to the taxa.
\end{abstract}

\section{Introduction}

McGillivray (1993: 453) placed the species examined here in his Group 1 (1.2.2). They share the following characters: perianth zygomorphic with limb symmetrical but not erect, the inner surface glabrous, ovary densely hairy (and usually either sessile or shortly stipitate), fruits with reddish stripes or blotches in the indumentum. Although both Grevillea triternata and G. ramosissima were regarded by Bentham (1870) as being more closely related to species in his Section 9, Conogyne, (Group 5 sensu McGillivray), the phenetic similarity in this case is superficial and appears to have arisen independently by a process of evolutionary convergence, probably in response to pollinator(s). Field observations have convinced us that McGillivray's treatment of G. triternata is inadequate and that recognition of $G$. raybrownii as a distinct species is warranted. Lectotypification of G. ramosissima var. hypargyrea $\mathrm{F}$. Mueller is necessary, since examination of the literature showed that the name was validly published. Field and herbarium studies have convinced us that continued recognition of this taxon at subspecific rank is also warranted.

Conservation codes follow Briggs and Leigh (1988: 7-13). Species descriptions and terminology follow McGillivray (1993) and Olde \& Marriott (1993a, 1993b).

\section{Key to species}

1 Style hairy over most of its length

3.G. ramosissima

$1^{*}$ Style glabrous over most of its length

2 Conflorescence cylindrical, relatively loose, the buds just before anthesis appressed and parallel to the rachis; pistils $<5 \mathrm{~mm}$ long; pedicels $<2 \mathrm{~mm}$ long

2.G. triternata

$2^{*}$ Conflorescence ovoid, dense, the buds just before anthesis spreading and irregularly orientated; pistils $6-7.5 \mathrm{~mm}$ long; pedicels $>3 \mathrm{~mm}$ long 
1. Grevillea raybrownii $P$. Olde $\mathcal{E} N$. Marriott, sp. nov.

A Grevillea triternata R. Br., conflorescentiis densioribus ovoideisque, indumento brunneo, gemmis conspicuis, densis, oblongo-ovoideis, nectario inconspicuo, pedicellis (3.5-4.2 $\mathrm{mm}$ longis) pistillisque (6-7 mm longis) longioribus, trichomatibus rubiginosis in ovarii indumento post anthesim crescentibus distinguitur.

Holotype: New SOUTH Wales: Central Tablelands: Waterboard Reserve near carpark, Welby, P. Olde 93/52 \& M. Olde, 26 Sep 1993 (NSW). Isotype: CANB, MEL, K, US.

A bushy shrub c. $1.5 \mathrm{~m}$ high; branchlets slightly angular with occasional ridges decurrent from the leaf bases, rusty-silky when very young. Leaves $2.5-5 \mathrm{~cm}$ long, ascending but the rachis sometimes recurved, subsessile but appearing petiolate, secund, bipinnatisect with the secondary lobes often divaricate; primary leaf lobes 3-5, narrow-linear to subulate, with secondary bi- to five-sect division, the highest orders of division on the more basal lobes; ultimate lobes $0.5-2.4 \mathrm{~cm}$ long, $0.6-1.2 \mathrm{~mm}$ wide, linear-subulate, pungent; upper surface glabrous with midvein and edge-veins evident; margin sharply and angularly refracted along the edge-vein; lower surface bisulcate, silky in the grooves, the midvein prominent. Conflorescences $1.5-1.7 \mathrm{~cm}$ long, $1.5 \mathrm{~cm}$ wide at the base, terminal or axillary, shortly pedunculate, ovoid, dense, c. 40-flowered, simple; buds oblong-ovoid, initiating and partially developed several months before proceeding to anthesis; peduncles c. $1 \mathrm{~mm}$ long and, with the floral rachises, sericeous; floral bracts $1.5 \mathrm{~mm}$ long, $2.2 \mathrm{~mm}$ wide, obovate to fan-shaped, brown-sericeous outside, persistent at anthesis. Flowers acroscopic but irregularly orientated; pedicels $3.5-4.2 \mathrm{~mm}$ long, silky; torus $0.5 \mathrm{~mm}$ across, oblique; nectary semi-annular, inconspicuous; perianth $2.5 \mathrm{~mm}$ long, $0.8 \mathrm{~mm}$ wide, cylindrical to slightly sigmoid, sericeous outside with white hairs, glabrous within; tepals coherent except along the dorsal suture split by exsertion of the style, separating and free to the base at anthesis, rolled back and soon detaching after; limb revolute, ferruginous, globose, completely enclosing the style-end before anthesis; pistil 6-7 mm long; stipe $0.1 \mathrm{~mm}$ long, silky; ovary subsessile, silky developing reddish hairs well after anthesis; style glabrous, geniculate $c$. half-way along, terminated by a suddenly expanded style-end; pollen-presenter $1 \mathrm{~mm}$ long, $0.8 \mathrm{~mm}$ wide, erect, conical, rising c. $0.5 \mathrm{~mm}$ above the oblique basal flange. Fruits $12 \mathrm{~mm}$ long, $5 \mathrm{~mm}$ wide, persistent, erect on incurved stipes, oblong-ellipsoidal with recurved apiculum, sericeous, the indumentum conspicuously red-striped and blotched on the dorsal side; style persistent; pericarp 0.3$0.5 \mathrm{~mm}$ thick. Seeds $9 \mathrm{~mm}$ long, $3.5 \mathrm{~mm}$ wide, obovoid-ellipsoidal; outer face wrinkled, convex, crimped submarginally with a broad, ridge-like margin; inner face with a central linear-elliptic area surrounded by a raised ridge; margin revolute with a waxy-papery wing all round drawn into an oblique, excurrent elaiosome at the apex. Figure 1.

ETYMOLOGY: The specific epithet honours Mr Raymond Brown (1947-), nurseryman of Bulli, New South Wales, for his contribution to the horticulture of Grevillea; he also first directed our attention to this species.

FLOWER COLOUR: Perianth white with hairs on the limb ferruginous; style white in the lower half, lilac in the upper half.

FLOWERING PERIOD: Spring.

Distribution: New South Wales, where restricted to an area bounded by Dapto, Robertson and Berrima.

Conservation status: $2 \mathrm{KC}$ suggested. This species has been collected in several localities but requires survey. It is known from at least one reserve.

HABITAT \& ECOLOGY: Grows in dry sclerophyll forest in sandy, gravelly loam derived from sandstone. Pollinator unknown. Regeneration is from seed. 
DisCUSSION: Grevillea raybrownii has dense, ovoid conflorescences with a conspicuous brown indumentum, dense, early-formed, oblong-ovoid floral buds, inconspicuous nectary, pedicels $3.5-4.2 \mathrm{~mm}$ long, pistils $6-7 \mathrm{~mm}$ long, red hairs not forming in the ovary indumentum until after anthesis. By contrast, $G$. triternata has relatively loose, shortly cylindrical conflorescences with a white indumentum, loose, late-formed, cylindrical floral buds, a relatively conspicuous nectary, pedicels $0.8-1.8 \mathrm{~mm}$ long, pistils $3.8-5 \mathrm{~mm}$ long. Red hairs are visible in the ovary indumentum of $G$. triternata well before anthesis. Most herbarium specimens of $G$. raybrownii collected in AprilMay have strongly developed floral buds. In fact, floral buds are more or less continuously present on mature shrubs.

In addition to these differences from G. triternata, G. raybrownii has leaves with consistently narrower, shorter (mostly 1-1.5 cm long) and less noticeably divaricate lobes, irregularly orientated flowers, a perianth limb that is strongly revolute before anthesis, the tepal-limbs much larger, a subsessile ovary with slower ovary enlargement after anthesis, its pollen-presenter broader at the base and rising in height about the same or less than its width. G. triternata, on the other hand, has markedly divaricate leaf lobes that are usually somewhat broader and longer (up to $3.5 \mathrm{~cm}$ long), its flowers adaxial and parallel both to themselves and to the rachis, a nodding perianth limb, its ovary usually clearly stipitate and enlarging well before anthesis, its pollen presenter clearly longer than the width of its base. Although McGillivray (MoGillivray 1993: 65-66) made some observations about morphology and distribution of populations referable to our G. raybrownii, he considered them to be part of G. triternata. However, given the number, kind and consistency of morphological differences between the two taxa, recognition of $G$. raybrownii at specific rank is clearly warranted.

NOTE ON MORPHOLOGY: The reddish colouration of hairs in the ovary indumentum appears to result from a chemical change in the hair-cell contents, possibly coinciding
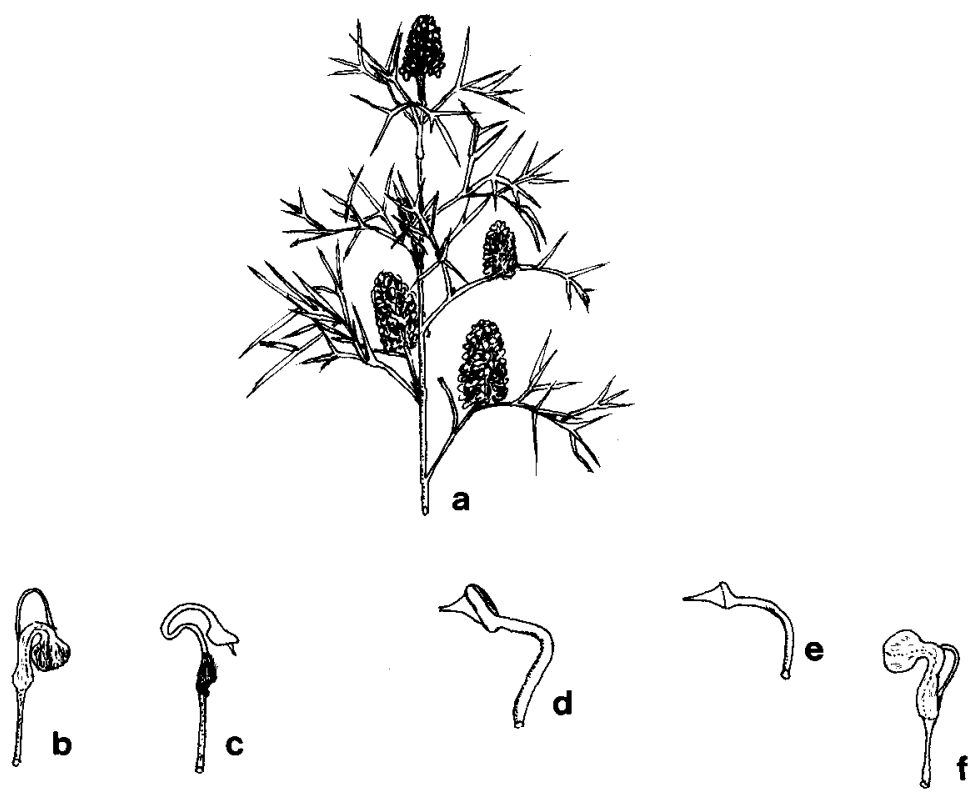

Figure 1. G. raybrownii: a. General habit (x0.5); b. perianth in late bud ( 22.5$)$; c. pistil (x2.5); d. style-end (x5). G, triternata: e. style-end (x5); f. perianth in late bud (x2.5). 
with fertilisation of the ovary. If the latter part of this observation is correct, then widespread autogamy is probable in G. triternata.

SelfCted SPECIMENS (from 18 examined): New South Wales: Central Coast: Divide between the Nattai River and Allum River, Olsen 2183, 25 Jun 1974 (NSW); West Dapto, Cambage, May 1904 (NSW). Central Tablelands: Berrima, Maiden, Sep 1901 (NSW, MEL 595889); Mundamar Creek track, old road through to Joadja, Stead, 5 Apr 1975 (NSW 136247); Vic. Bullio tunnel, Mittagong-Wombeyan Caves Rd, Taylor 366, Goodwin, Bishop \& Gunnell, 10 Dec 1984, (NSW, B, CBG, K, PERTH, RSA); $19.2 \mathrm{~km}$ NE of Robertson on No. 1 fire trail in the catchment area of the Avon Dam, Coveny 848, 24 Feb 1969 (NSW).

\section{Grevillea triternata $R . B r$.}

Brown (1830: 21).

LeCtOTYPe (McGillivray 1993: 445-446): New South Wales: Oxleys $2^{\text {d }}$ Expedition n. 43 Fraser 43 (BM - two specimens at the base of the sheet; n.v.).

\section{Anadenia triternata A. Cunn. ex G. Heynhold (1846) nomen inval.}

A dense, compact shrub $0.2-1 \mathrm{~m}$ high; branchlets angular, sometimes ridged, silky. Leaves 3-8 cm long, ascending, shortly petiolate, the rachis refracted at the nodes, divaricately bipinnatisect to triternate, sometimes bipinnatifid; primary leaf lobes $3-5$, oblong to narrowly oblong, usually with secondary or tertiary division; ultimate lobes $0.7-3.5 \mathrm{~cm}$ long, $1-4 \mathrm{~mm}$ wide, linear or linear-subulate, triangular to elliptic, pungent; margin angularly refracted to smoothly revolute; upper surface flat to longitudinally slightly v-shaped, glabrous or with scattered trichomes, the midvein evident within a shallow groove; lower surface bisulcate or the lamina either exposed beside the midvein or in some specimens mostly enclosed but exposed at the sinuses of some leaves, silky in the grooves or on the exposed parts, midvein prominent. Conflorescence terminal or axillary in the upper leaf axils, enclosed well within the foliage, unbranched or sometimes 1-branched at the base; unit conflorescence 1-2.8 $\mathrm{cm}$ long, $0.5-0.8 \mathrm{~cm}$ wide, shortly cylindrical, moderately dense, $c$. 20-flowered, proceeding quickly to development after bud initiation; peduncles and floral rachises white-sericeous; floral bracts $0.8-2.3 \mathrm{~mm}$ long, spreading to patent, ovate, whitesericeous outside, persistent at anthesis or deciduating just before. Flowers adaxially orientated and parallel to the rachis; pedicels $0.8-1.8 \mathrm{~mm}$ long, sericeous; torus \pm 0.5 $\mathrm{mm}$ across, oblique; nectary linguiform; perianth $2-3 \mathrm{~mm}$ long, $0.8 \mathrm{~mm}$ wide, cylindrical to sigmoid, white-sericeous outside, glabrous inside; tepals coherent before anthesis except along the dorsal suture where separate to the base through exsertion of the style, all separating and free to the base at anthesis, rolling back and away after; limb nodding, globular, white-sericeous, the style-end completely enclosed before anthesis; pistil 3.8-5 mm long; stipe $0.1-0.5 \mathrm{~mm}$ long, sericeous; ovary oblique to the stipe, sericeous with a reddish, dorsal stripe, ovoid with dorsal concavity, enlarging before anthesis; style glabrous except a few basal hairs sometimes up to $1.5 \mathrm{~mm}$ above ovary, retrorse in the lower half but conspicuously inflected c. the middle, terminated by a broadly expanded style-end; pollen presenter $0.6 \mathrm{~mm}$ long $0.6 \mathrm{~mm}$ wide, conical, rising $0.8 \mathrm{~mm}$ above its straight to slightly oblique base. Fruits oneseeded, anteriorly oblique on stipes sharply inflexed through c. $60^{\circ}-90^{\circ}$, obliquely ellipsoid to slightly ovoid, 6.5-8.5(-9.5) mm long, (4.5-)5-7 mm wide, 4-5.5 mm thick; styles persistent; indumentum subsericeous, usually with red-brown stripes or blotches predominantly in the dorso-lateral region, the markings composed of hairs with dark contents; surface beneath the indumentum rugulose and sometimes also granulose, slightly ridged about the dorsal side, especially towards the base and apex; pericarp $(0.3-) 0.4 \mathrm{~mm}$ across at the suture, c.0.4-0.6 mm thick at centre face and at the dorsal side; texture crustaceous; fruits opening widely after dehiscence. Seeds elliptical, 6-7 $\mathrm{mm}$ long, $3.5-4 \mathrm{~mm}$ wide, c. $2.5 \mathrm{~mm}$ thick, outer face strongly convex and with a 
peripheral ridge, wrinkled [?slightly immature]; inner face with a submarginal ridge c. $0.4 \mathrm{~mm}$ high, and a central longitudinal ridge c. $0.5-1 \mathrm{~mm}$ wide, c. $0.5 \mathrm{~mm}$ wide and 3-4 mm long, the two ridges separated by a trough c. $0.5-1 \mathrm{~mm}$ wide, and along the anterior edge of the seed a chartaceous border c. $0.1-0.2 \mathrm{~mm}$ wide on the outer ridge (Fruits \& Seeds from McGillivray 1993: 66).

Flower COLOUR: Perianth and style creamy-white to yellowish.

FLOWERING PERIOD: Spring.

Distribution: New South Wales: between Kerrabee and Bathurst north-west to Coonabarabran and the Pilliga area and east to Inverell, Howell and the Gibraltar Range.

CONSERVATION STATUS: Not presently endangered.

HABITAT \& ECOLOGY: Grows in sandy soil over sandstone or granite, sometimes in loamy conglomerate, on steep rocky slopes or in flat, eucalypt woodland. Pollination is probably by insects but there is also strong evidence of selfing. Regeneration is from seed and root-sucker (pers. obs.). Root-suckering was common in most populations visited in the field.

Discussion: Consideration was given to recognising two subspecies in G. triternata based on leaf-lobe width, following observations by McGillivray, and our own field work, that plants with this morphological feature occurred in consistent, geographically disjunct populations (McGillivray 1993: 66-67). However, examination of the specimens at NSW indicates that this character on its own is insufficient. Particular reference is made to two specimens with broad lobes (Forsyth s.n. from Warrumbungle Ranges and Makinson s.n. from Sid Cadwell's property near Rylstone) that have been collected from areas where narrow-lobed forms have otherwise been exclusively collected. Further studies in this species, including specimens treated as unassigned between G. triternata and G. ramosissima by McGillivray (McGillivray 1993: 65), are clearly justified.

Selected SPECiMENS (from 42 examined): New South Wales: Central Tablelands: Murrumbo, Baker, Oct 1893 (NSW); Growee Gulph, Hind 2199, 17 Nov 1977 (NSW); Winburndale Nature Reserve, $20 \mathrm{~km}$ E of Bathurst, Coveny 9648, 2 Oct 1977 (NSW). Central Western Slopes: slopes of Widdin Valley, Briggs 1342 \& Johnson, 1 Oct 1967 (NSW); between Dubbo and Mendooran, G. Althofer 41, Mar 1946 (NSW). North Western Slopes: Warialda, Maiden, Aug 1905 (NSW); Warrumbungle Ranges, Forsyth, Oct 1899 (NSW); Howell, SSW of Inverell, McGillivray 3996 \& Makinson, 7 Sep 1982 (NSW); Stannifer, $7 \mathrm{~km}$ N of Tingha, Rodd 4073, 21 Nov 1984 (NSW). Northern Tablelands: Chandlers' Peak, c. 8 miles [13 km] directly E. of Guyra, Boorman, Mar 1917 (NSW).

\section{Grevillea ramosissima Meisner}

Meisner (1855: 74)

A full description is given in McGillivray (1993: 64-65).

\section{Key to subspecies of G. ramosissima}

1 Leaf undersurface tomentose with twisted or curly hairs, rarely with an ascending indumentum of straight hairs; conflorescences $2.5-4(-5) \mathrm{cm}$ long; leaf texture coriaceous subsp. ramosissima

$1^{*}$ Leaf undersurface sericeous; conflorescences $4.5-5.5(-10)$ am long; leaf texture firmly chartaceous subsp. hypargyrea 
Grevillea ramosissima subsp. hypargyrea (F. Muell.) P. Olde $\mathcal{E}$ N. Marriott, stat. nov.

BASIONYM: Grevillea ramosissima var. hypargyrea F. Mueller, Fragm. 8: 150 (1874)

TYPe CITATION: 'Grevillea ramosissima (Meisn. in Cand. Prodr. xiv. 388) in montibus granitico-rupestribus ad flumen Humei varietatem hypargyream, foliis subtus pulchre argenteo-sericeis, producit.'

LeCTOTYPE (here designated): Humes River, Jan 1874. 6' Granitic Mountains on the lower Hume's River, F. Mueller (MEL 72020). Isolecto MEL 72019.

A single-stemmed or root-suckering shrub $0.3-1.5 \mathrm{~m}$ tall; branchlets rounded, silkytomentose with fawn, white and brown hairs, the hairs reddish when young. Leaves 5-8.5 cm long, 4-7 cm wide, ascending, shortly petiolate, bipinnatifid; primary leaf lobes 3-7, oblong, ascending, bi- or trifid; ultimate lobes 3-12 $\mathrm{mm}$ long, 2-5 mm wide, triangular, terminated by an excurrent spine $2-3 \mathrm{~mm}$ long; upper surface sparsely silky, slightly raised yellowish midvein, lateral and intramarginal veins, the undersurface white-silky with raised orange-fawn venation clothed in tardily deciduous white and brown hairs; margin angularly refracted about the intramarginal vein; texture firmly chartaceous. Conflorescence terminal, usually few-branched; unit conflorescence $4.5-5.5(-10) \mathrm{cm}$ long, cylindrical, loose; peduncles and floral rachises silky; floral bracts $1.5-2 \mathrm{~mm}$ long, $1 \mathrm{~mm}$ wide, linear-elliptic, tomentose-villous outside, persistent at anthesis. Flowers adaxially orientated and parallel; pedicels $1.2 \mathrm{~mm}$ long, silky; torus $\pm 0.5 \mathrm{~mm}$ wide, oblique; nectary obscure; perianth 3-4 mm long, 1 $\mathrm{mm}$ wide, oblong-ovoid, tomentose outside, glabrous inside; limb revolute, globose, each segment bearing an obscure apical protuberance; pistil $4.5 \mathrm{~mm}$ long; stipe c. 0.2 $\mathrm{mm}$ long, obscured by indumentum; ovary silky-tomentose; style silky in the lower half with scattered white trichomes over the apical half; pollen-presenter $0.6 \mathrm{~mm}$ long, erect, conical. Fruits 8-9 mm long, 5-6 mm wide, ovoid to almost round, apiculate with persistent style, the outer surface velutinous with reddish stripes or blotches in the upper half. Seeds not seen.

FLOWER COLOUR: Perianth and style creamy-white.

FLOWERING PERIOD: Spring.

Distributron: Victoria, where confined to the north-east in a number of small populations in the Pine Mountain-Cudgewa Bluff area and on several mountains of the Upper Murray River. A collection in 1884 from the Upper Ovens River needs verification. The collection from Mt. Mittamatite, McKinnan, (MELU) has not been seen. However, the distribution at this locality is confirmed (pers. obs.).

CONSERVATION STATUS:Not presently endangered.

HABITAT \& ECOLOGY: Grows on hillsides among granite boulders in granitic loam, usually in eucalypt woodland. Pollination is probably by insects. Regeneration is from seed or root-suckers.

Discussion: McGillivray (1993: 64) referred to the Victorian populations of G. ramosissima as the 'silky-leaved form'. Examination of the literature showed that this form had been previously described as var. hypargyrea (Mueller 1874: 150). Moreover, our studies show that consistent morphological differences exist between the Victorian and New South Wales populations and that formal recognition is warranted. Ranking this taxon here as subspecies rather than continuing recognition as variety provides conformity with equivalent taxa in the genus and acknowledges the population basis and geographic disjunction of its occurrence. Subsp. hypargyrea differs from subsp. ramosissima in its generally thinner leaves with finer venation and sericeous undersurface and in its usually longer and somewhat looser conflorescences. Some of these 
differences have been documented by MoGillivray (1993: 64-65). There is a geographic disjunction of $50 \mathrm{~km}$ between the most southern population of subsp. ramosissima and the most northern population of subsp. hypargyrea.

Selected SPECIMENS (10 examined): Victoria: Beside Murray Valley Highway at foot of Pine Mt, Corrick 5982, 29 Oct 1972 (MEL 526370); E. Pine Mountain, Willis s.n., (MEL 72025); Upper Murray River, French, Jan 1886 (MEL 72013); Pine Mountain, Walter, Nov 1891 (MEL 560246); Hume River, McGibbin s.n., undated, (MEL 72021); Walwa, lower Humes River, Mueller, Jan 1874, (MEL 72019); Mt Mittamatite, McKinnan, 7 Oct 1968 (MELU) n.v.

\section{Acknowledgements}

We wish to thank the Directors of the National Herbarium of New South Wales (NSW) and the National Herbarium of Victoria (MEL) for allowing access to their collections. Special thanks also to Dr. L.A.S. Johnson who critically read earlier drafts of this manuscript.

\section{References}

Bentham, G. (1870) Flora australiensis, vol. 5 (Reeve \& Co.: London).

Briggs, J.D. \& Leigh, J.H. (1988) Rare or threatened Australian plants. Austral. Nat. Parks \& Wildlife Service, Special Publication No 14.

Brown, R. (1830) Supplementum primum prodromi florae Novae Hollandiae (Richard Taylor: London).

McGillivray, D.J. (1993) Grevillea. (Melbourne University Press: Melbourne).

Meisner, C.F. (1855) New Proteaceae in Australia. Hooker's Journ. Bot. Kew Gard. Misc. 7: 64-78. Mueller, F. von (1874) Fragmenta Phytographiae Australiae vol. 8.

Olde, P.M. \& Marriott, N.R. (1993a) A taxonomic revision of Grevillea angulata (Proteaceae: Grevilleoideae) and closely related species from the Northern Territory and Western Australia. Telopea 5(2): 399-41.

Olde, P.M. \& Marriott, N.R. (1993b) New species and taxonomic changes in Grevillea (Proteaceae: Grevilleoideae) from south-west Western Australia. Nuytsia 9(2): 237-304. 